\title{
New records to the Korean soil dwelling Mesostigmata fauna (Acari)
}

\author{
Jenö Kontschán ${ }^{1, *}$, Mi Jeong Jeon ${ }^{2}$, Jeong Mi Hwang ${ }^{3}$ and Hong Yul Seo ${ }^{2}$ \\ ${ }^{1}$ Plant Protection Institute, Centre for Agricultural Research, Hungarian Academy of Sciences, H-1525 Budapest, \\ P.O. Box 102, Hungary \\ ${ }^{2}$ Animal Research Division, National Institute of Biological Resources, Gyoungseo-dong, Seo-gu, \\ Inchoen 404-708, Korea \\ ${ }^{3}$ Korean Entomological Institute, Korea University, Anam-dong, Seongbuk-gu, Seoul 136-701, Korea \\ *Correspondent: kontschan.jeno@agrar.mta.hu
}

\begin{abstract}
A total of 34 species belonging to 11 families and 21 genera in the Order Mestostigmata are reported from the Korean Peninsula, of which 20/34 species are new for the fauna of the Korean Peninsula (Lasioseius furcisetus Athias-Henriot, 1959, Cheiroseius nepalensis Evans \& Hyatt, 1960, Cheiroseius curtipes (Halbert, 1923), Hypoaspis imitatus Reitblat, 1963, Hypoaspis presternalis Willmann, 1949, Hypoaspis kargi Costa, 1968, Pseudoparasitus placentulus (Berlese, 1887), Gamasiphis novipulchellus Ma \& Yin, 1998, Parholaspulus bregetovaae Alexandrov, 1965, Parholaspulus paradichaetes Petrova, 1967, Neparholaspis arcuatus Petrova, 1977, Neparholaspus simplex Evans, 1956, Parholaspulus excentricus Petrova, 1967, Gamasholapis asiaticus Petrova, 1967, Veigaia carpillaris Tseng, 1994, Veigaia anmashanensis Tseng, 1994, Leptogamasus bicorniger Witalinski, 1977, Neogamasus insignis (Holzman, 1969), Iphidinychus kakumeiensis Hiramatsu \& Hirschmann, 1992, Trigonuropoda sanguinea Hirschmann \& Hiramatsu, 1977). A total of 19 of the previously unreported species were collected in soil samples from the Democratic People's Republic of Korea (DPRK), while 13 species were collected from soil samples from the Republic of Korea (ROK). Only two species were found in both the DPRK and the ROK. Illustrations and short descriptions for previously unreported species provided.
\end{abstract}

Keywords: Korean Peninsula, Mesostigmata, mites, new records

(C) 2015 National Institute of Biological Resources

DOI:10.12651/JSR.2015.4.1.033

\section{INTRODUCTION}

The order Mesostigmata is one of the most intensively studied groups of the mites worldwide and contains species that are widely variable in size and morphology. Mesostigmatid mites are predators and found in soil, leaf litter, and low-lying vegetation (e.g. mosses) worldwide. The mesostigmatid mites are very diverse group of the mites from morphological point of view. The common characters of all Mesostigmata are the four pairs of setae on ventral part of gnathosoma and the strongly sclerotized plates on ventral and dorsal part of the body and the presence of tritosternum (Krantz and Walter, 2009). The Mesostigmata fauna of Korean Peninsula have been only recently been investigated and have concentrated on several families, including the Ascidae (Lee, 1994; Lee and Lee, 1996; 1998; Lee et al., 1997), Parholaspididae, Podocinidae (Lee and Lee, 2000), and Zerconidae (Błaszak, 1976a; 1976b; Lim, 2001). More recently, Kontschán et al. (2012; 2013; 2014a; 2014b) have intensively studied mesostigmatid mites of the Korean peninsula.

The Soil Zoology Collection at the Hungarian Natural History Museum has an extensive large collection of unsorted soil samples collected throughout the Korean Peninsula, including from the Republic of Korea (ROK) and the Democratic People's Republic of Korea (DPRK), which was recently examined for mesostigmatid mites and reported by Kontschán et al. (2012; 2013; 2014a; 2014b). In this investigation, more than 200 soil samples housed in this collection were examined for mesostigmatid mites and reported herein, including illustrations and short descriptions for previously unreported species. 


\section{Materials and Methods}

Soil from more than 200 soil samples collected from various areas in the ROK and DPRK and maintained at the Soil Zoology of Hungarian Natural History Museum (Budapest, Hungary) (HNHM) were examined using Leica DM 1000 microscope $(100 \times)$ for mesostigmatid mites (Appendix 1). The specimens were cleared in lactic acid and observed in the deep and half covered slides in scientific microscope or prepared on slide with Kaiser Fluid or lactic acid and gelatin mixture. Illustrations were made with a drawing tube, photographs taken with a Nikon CoolPix900 digital camera.

All specimens that were examined were deposited in the Soil Zoology Collection of Hungarian Natural History Museum (HNHM), Budapest, Hungary or the National Institute of Biological Resources (NIBR), Incheon, Republic of Korea. Scanning micrographs were taken in the Hungarian Natural History Museum, Budapest with a HITACHI SN 2600 scanning electronmicroscope; the specimens investigated were spatter-coated with gold-palladium. In the case of the Mesostigmata, only the females are identified exactly in species level, therefore we presented our results based on only females. Measurements are given in micrometers $(\mu \mathrm{m})$, width of idiosoma was taken at the level of coxae IV.

\section{Results}

A total of 34 mites belonging to the Order Mesostigmata were collected from 22 soil samples from the ROK and DPRK.

\section{List of the species found}

Order Mesostigmata

Family Ascidae Oudemans, 1905

\section{Asca sculptrata Aoki, 1968}

New localities. As660 Republic of Korea, Prov. Jeju, Halla-san National Park, same site moss and soil samples (four different items) were taken from mosses, detritus, litter and upper layers of soil, 30.X.1993, leg. Peregovits, L. and Ronkay, L.

Previous record from Korean Peninsula. Republic of Korea (Lee, 1994).

Distribution. Japan and Korean Peninsula.

\section{Lasioseius tomokoae Ishikawa, 1969}

New localities. As659 Republic of Korea, Prov. Jeju, Halla-san National Park, same site moss and soil samples (four different items) were taken from mosses, detri- tus, litter and upper layers of soil, leg 30.X.1993. 10, leg. Peregovits, L. and Ronkay, L.

Previous record from Korean Peninsula. Democratic People's Republic of Korea, North Pyongan Prov. (Kontschán et al., 2014a)

Distribution. Japan and Korean Peninsula.

\section{Lasioseius furcisetus Athias-Henriot, 1959 (Fig. 1a)}

New localities. Republic of Korea, Prov. Jeju, Halla-san National Park, same site moss and soil samples (four different items) were taken from mosses, detritus, litter and upper layers of soil, leg 30.X.1993, leg. Peregovits, L. and Ronkay, L.

Short description. Dorsal shield covered by small oval pits which formed a web-like structures. Dorsal setae apically wider and peaked. Setae J6 short and needle-like. Previous record from Korean Peninsula. -

Distribution. Russia.

Remarks. New for the Korean fauna.

Cheiroseius nepalensis Evans \& Hyatt, 1960 (Fig. 1b) New localities. As541 Democratic People's Republic of Korea, South Hwanghae Province, Haeju, Mt. Suyongsan, moss, 30.XI.1986, leg. Demeter, A.

Short description. Dorsal setae smooth, simple and needle-like. Dorsal shield covered by reticulate sculptural pattern. Sternal shield with three pairs of need-like setae, St 4 situated on small and rounded platelets at level of coxae III. Anal shield circle, bearing seven pairs of needle-like setae.

Previous record from Korean Peninsula. -

Distribution. Russia and Nepal.

Remarks. New for the Korean fauna.

\section{Cheiroseius curtipes (Halbert, 1923) (Fig. 1c)}

New localities. As665 Korea, Prov. Jeju, Halla-san National Park, sandy soil with small rocks, 30.X.1993, leg. Peregovits, L. and Ronkay, L.

Short description: Dorsal setae smooth, simple and needle-like. Dorsal shield covered by reticulate sculptural pattern, between setae $\mathrm{J} 1$ and $\mathrm{J} 2$ a rounded ornamentation situated. Sternal shield with three pairs of need-like setae, St4 situated on small and oval platelets at level of coxae III. Anal shield oval, wider than long, bearing nine needle-like setae.

Previous record from Korean Peninsula: -

Distribution. Europe and Asia

Remarks. New for the Korean fauna.

Family Hypoaspididae Vitzthum, 1941

Hypoaspis imitatus Reitblat, 1963 (Fig. 1d).

New localities. As572 Democratic People's Republic of Korea, Kangwon Province: Kumang-san, Onjong-ri, sam- 
ple taken from pitfall traps baited with beer in Pinus densiflora-forest, 21-17.VI.1988, leg. Merkl, O. and Szél, Gy.

Short description. Idiosoma oval. Genital shield large with three pairs of needle-like setae and reticulate sculptural pattern. Anal shield separated from genital shield, with two short adanal setae and a long postanal seta.

Previous record from Korean Peninsula. -

Distribution. Europe and Asia.

Remarks. This is the first record from the Korean Peninsula.

\section{Hypoaspis presternalis Willmann, 1949 (Fig. 1e)}

New localities. As282 Democratic People's Republic of Korea, Prov. Ryang-gang: Chann-Pay plateau, Mt. Pektusan, Mu-do-bong, moss and lichen samples from the upper level of Larix-Betula forest, 25.VI.1975, leg. Papp, J. and Vojnits, A.

Short description. Dorsal shield with reticulate sculptural pattern and bearing needle-like setae. Dorsal setae short not reach the next ones. Genital shield of female linguliform, sternal ventrianal and genital shield covered by reticulate sculptural pattern. Presternal shields fused and formed a large and reticulate plate on anterior margin of sternal shield. Between genital and ventrianal shield two pairs of needle-like setae situated.

Previous record from Korean Peninsula. -

Distribution. Europa and Asia.

Remarks. New for the Korean fauna.

\section{Hypoaspis kargi Costa, 1968}

New localities. As216 Democratic People's Republic of Korea, Prov. Kanwon: Kum-gang sen, Guriong chon, riverside northern slope, litter and underlying ground from below coniferous trees, 01.VI.1970, leg. Mahunka, S. and Steinmann, $\mathrm{H}$.

Short description. Dorsal shield with reticulate sculptural pattern and bearing needle-like setae. Dorsal setae short reach the next ones. Genital shield of female linguliform, shields on ventral idiosoma covered by reticulate sculptural pattern. Presternal shields fused and formed a large and reticulate plate on anterior margin of sternal shield. Between genital and ventrianal shield two pairs of needle-like setae situated.

Previous record from Korean Peninsula. -

Distribution. Europa and Asia.

Remarks. New for the Korean fauna.

\section{Pseudoparasitus placentulus (Berlese, 1887) (Fig. 1f)}

New localities. As230 Democratic People's Republic of Korea, Prov. Ryang-gang: Mt. Pektusan, soil sample of Acari extracted, 26.VIII.1971, leg. Papp, J. and Horvatovich, $\mathrm{S}$.

Short description. Idiosoma large and oval, ventrianal and genital shield fused, this large shield with reticulate sculptural pattern and seven pairs of setae.

Previous record from Korean Peninsula. -

Distribution. Europe and Asia.

Remarks. New for the Korean fauna.

Family Ologamasidae Ryke, 1962

\section{Gamasellus humosus Ishikawa, 1969}

New localities. As215 Democratic People's Republic of Korea, Prov. Kanwon: Kum-gang san, Guriong chon riverside northern slope, mosses from soil surface and cliffside, 01.VI.1970, leg. Mahunka, S. and Steinmann, H. As660 Republic of Korea, Prov. Jeju, Halla-san National Park, same site moss and soil samples (four different items) were taken from mosses, detritus, litter and upper layers of soil, 30.X.1993, leg. Peregovits, L. and Ronkay, L. As661 Republic of Korea, Prov. Jeju, Halla-san National Park, same site moss and soil samples (four different items) were taken from mosses, detritus, litter and upper layers of soil, 30.X.1993, leg. Peregovits, L. and Ronkay, L.

Previous record from Korean Peninsula. Democratic People's Republic of Korea, Kanwon Province (Kontschán et al., 2014a).

Distribution. Japan and Korean Peninsula.

\section{Gamasiphis pulchellus (Berlese, 1887)}

New localities. As573 Democratic People's Republic of Korea, Kangwon Province: Kumang-san, Onjong-ri, sifting forest litter and rotten trunks of Pinus densiflora, 19.VI.1988, leg. Merkl, O. and Szél, Gy.

Previous record from Korean Peninsula. Democratic People's Republic of Korea, South Phenan Province (Kontschán et al., 2014a).

Distribution. Europe and Asia.

\section{Gamasiphis novipulchellus Ma \& Yin, 1998 (Fig. 1g-h)}

New localities: As199 Democratic People's Republic of Korea, Prov. South Phenjan: De-sang san, 12 km NE from Pyongyang, dry SW slopes of the mountain, Thick coniferous litter under pine tree, 27.V.1970, leg. Mahunka, S. and Steinmann, $\mathrm{H}$.

Short description. Small rounded mites, anterior to sternal shield with two pairs of prestenal platelets. All setae with sharp tips, setae $\mathrm{j} 6$ shorter than the distance of their basis and JV5 present.

Previous record from Korean Peninsula. -

Distribution. China and Korean Peninsula.

Remarks. New for the Korean fauna.

Family Parholaspididae Evans, 1956

Parholaspulus hiasmaticus Petrova, 1967 

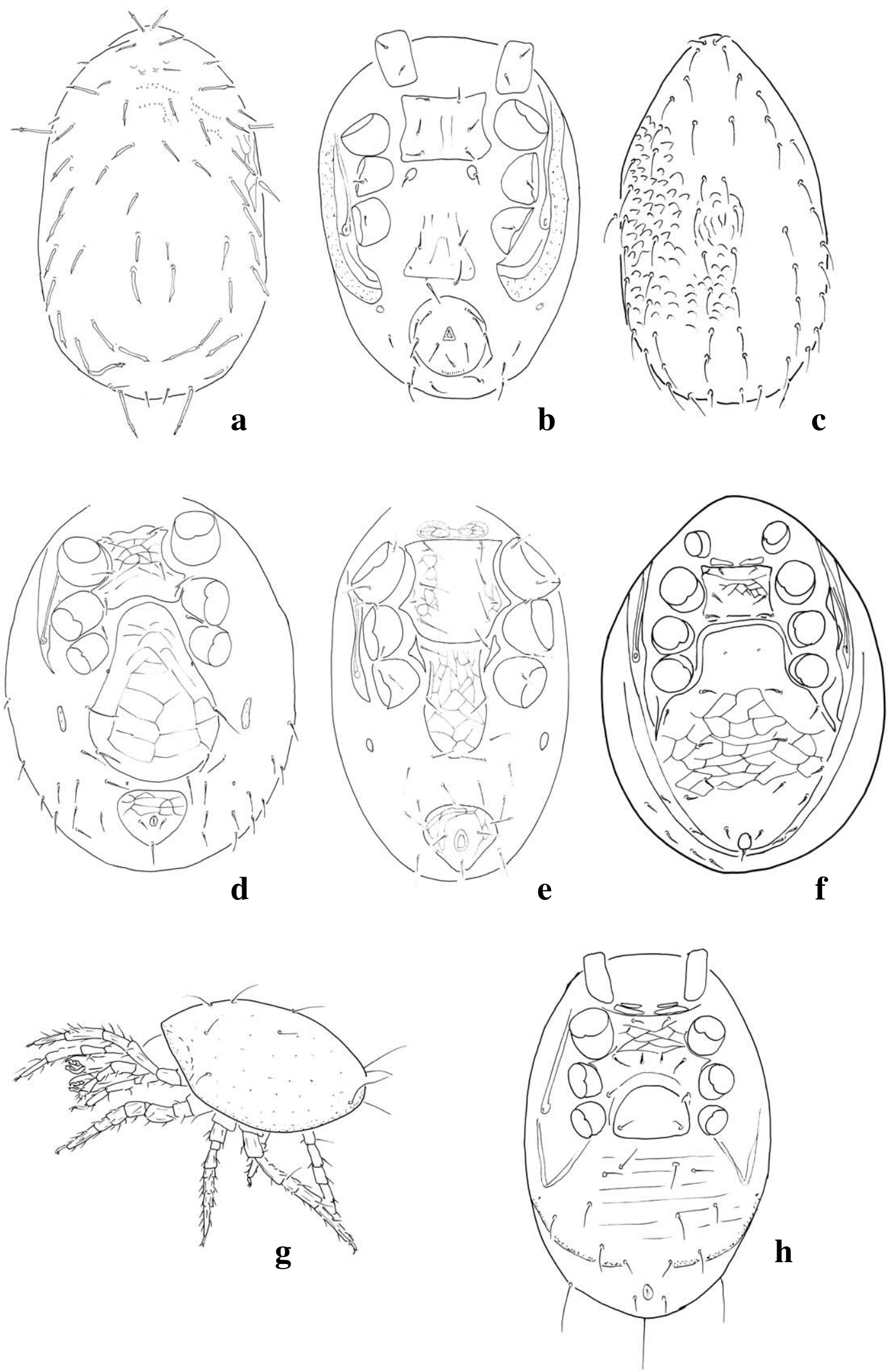

Fig. 1. Mesostigmatid mites from the Korean Peninsula I (a. Lasioseius furcisetus, dorsal view. b. Cheiroseius nepalensis, ventral view. c. Cheiroseius curtipes, dorsal view. d. Hypoaspis imitatus ventral view. e. Hypoaspis presternalis, ventral view. f. Pseudoparasitus placentulus, ventral view. g. latera- and h. ventral view of Gamasiphis novipulchellus). 
New localities. As273, Democratic People's Republic of Korea, Prov. South Pyongan: Pyongyan, De-sang san, $12 \mathrm{~km}$ NE from Pyongyan, moss sample from a coniferous wood, 18.VII.1975, leg. Papp, J. and Vojnits, A. As279 Democratic People's Republic of Korea, Prov. South Pyongan: Pyongyan, De-sang san, $12 \mathrm{~km} \mathrm{NE}$ from Pyongyan, litter sample from a coniferous wood, 18 VII.1975, leg. Papp, J. and Vojnits, A.

Previous record from Korean Peninsula. Democratic People's Republic of Korea, North Pyongan Prov. (Kontschán et al., 2014a).

Distribution. East-Russia and Korean Peninsula.

Parholaspulus bregetovaae Alexandrov, 1965 (Fig. 2a) New localities. As557 Democratic People's Republic of Korea, North Pyongan Prov., Mt. Myohyang-san, material extracted of the litter of a mixed forest on the bank of these stream Hyangsam by Moczarsky-Winkler-funnel, 08.X.1987, leg. Korsós, Z. and Ronkay, L.

Short description. Dorsal setae needle-like, row $\mathrm{j}$ and $\mathrm{J}$ situated laterally from central axis. Sternal, genital and ventrianal shields mostly smooth. Tritosternum with three branches.

Previous record from Korean Peninsula. -

Distribution. East-Russia and Korean Peninsula.

Remarks. New for the Korean fauna.

Parholaspulus paradichaetes Petrova, 1967 (Fig. 2b-c) New localities. As235 Democratic People's Republic of Korea, Prov. South Pyongan: Pyongyan, Pyongyan Hotel garden, soil sample of Acari, 21.VIII.1971, leg. Papp, J. and Horvatovich, S.

Short description. Dorsal setae smooth, long and needlelike, except two pairs setae situated near $\mathrm{j} 1$, which are short. Sternal shield without sculptural pattern, only a lateral ribbing can be seen on it. Tectum with a long central branch.

Previous record from Korean Peninsula. -

Distribution. East-Russia and Korean Peninsula.

Remarks. New for the Korean fauna.

\section{Parholaspulus excentricus Petrova, 1967 (Fig. 2d)}

New localities. As659 Republic of Korea, Prov. Jeju, Halla-san National Park, same site moss and soil samples (four different items) were taken from mosses, detritus, litter and upper layers of soil, leg 30.X.1993, leg. Peregovits, L. and Ronkay, L.

Short description. Sternal shield, ventral and genital shields covered by small oval pits which ordered in tilelike sculptural pattern, only a lateral ribbing can be seen on it. Tectum with a long bifurcated central branch.

Previous record from Korean Peninsula. Distribution. East-Russia and Korean Peninsula. Remarks. New for the Korean fauna.
Notes. The found specimen differs from the original description in some characters. It would be necessary to search other specimens to decide that this is a new subspecies or not.

\section{Holaspina trifurcatus (Ishikawa, 1966)}

New localities. As665 Democratic People's Republic of Korea, Prov. Jeju, Halla-san National Park, sandy soil with small rocks, 30.X.1993, leg. Peregovits, L. and Ronkay, L.

Previous record from Korean Peninsula. This species was recorded from Korean Peninsula by Lee \& Lee (2000).

Distribution. Japan and Korean Peninsula.

\section{Holaspulus serratus (Ishikawa, 1980)}

New localities. As665 Democratic People's Republic of Korea, Prov. Jeju, Halla-san National Park, sandy soil with small rocks, 30.X.1993, leg. Peregovits, L. and Ronkay, L.

Previous record from Korean Peninsula. This species was recorded from Korean Peninsula by Lee \& Lee (2000).

Distribution. Japan and Korean Peninsula.

\section{Neparholaspis bisunensis Lee \& Lee, 2000}

New localities. Korea1: Republic of Korea, Seoul, Korea University, Dukso farm, wet leaf litter under an unknown tree and under Gingko biloba, 11.VIII.2013, leg. J. Kontschán.

Previous record from Korean Peninsula. This species was described from Korean Peninsula by Lee \& Lee (2000). Distribution. Republic of Korea.

Remarks. This species seems to be an endemic Korean species.

\section{Neparholaspis arcuatus Petrova, 1977 (Fig. 2e)}

New localities. As583 Democratic People's Republic of Korea, Kumguang-san, forest leaf litter, 07.IX.1989, leg. Szollát, Gy.

Short description. Sternal shield with a T-shaped strongly sclerotized line and some oval pits, genital and ventrianal shields with reticulate sculptural pattern. Peritrematal shield fused to ventrianal shield, epistome weve-like, with a rounded apical margin.

Previous record from Korean Peninsula. -

Distribution. East-Russia and Korean Peninsula.

Remarks. This is the first record in Korean Peninsula.

\section{Neparholaspus simplex Evans, 1956 (Fig. 2f)}

New localities. As664 Democratic People's Republic of Korea, Prov. Jeju, Halla-san National Park, leaf litter and soil, 30.X,1993, leg. Peregovits, L. and Ronkay, L. Short description. Sternal shield with a T-shaped strongly 


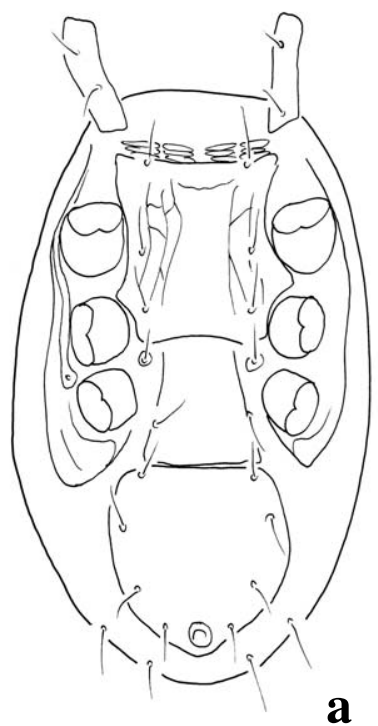

$\mathbf{a}$

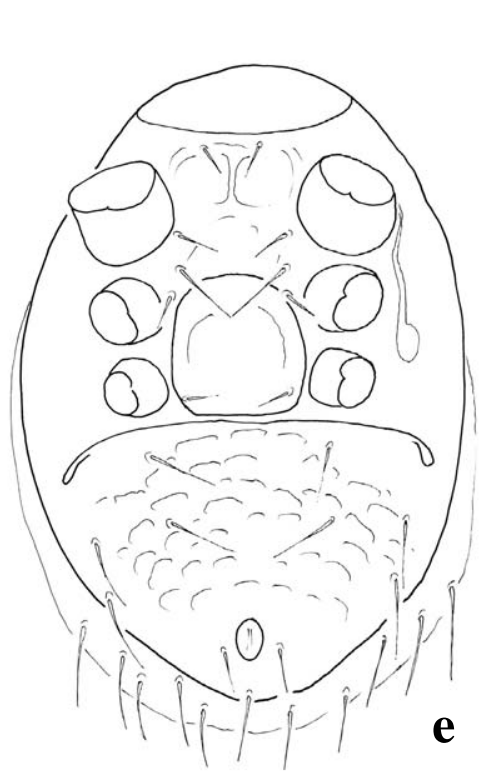

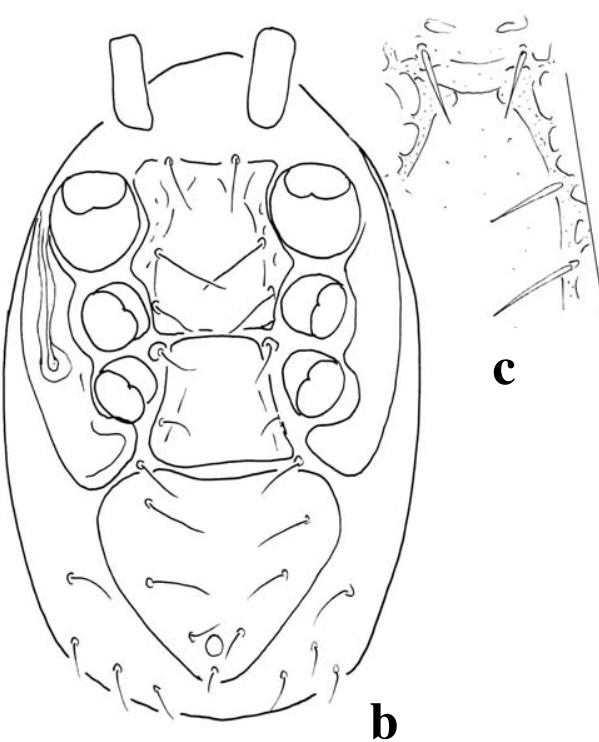

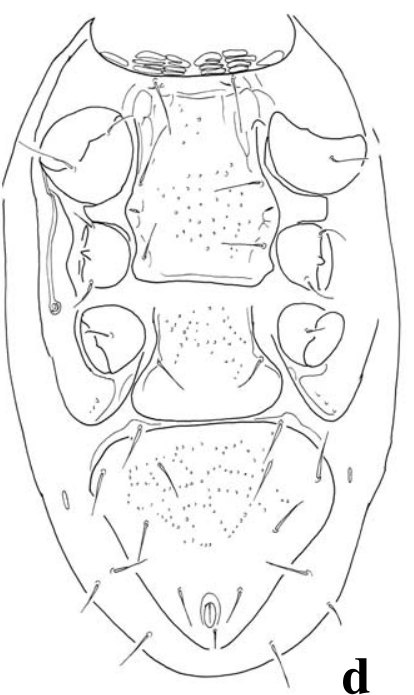

d
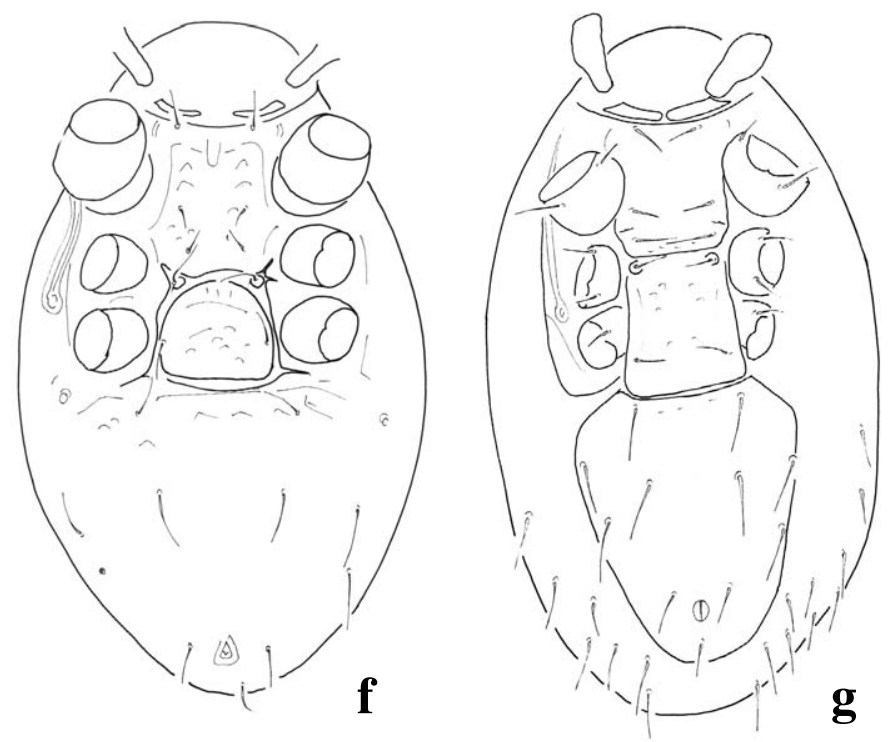

Fig. 2. Mesostigmatid mites from the Korean Peninsula II (a. ventral view of Parholaspulus bregetovaae. b. ventral view of Parholaspulus paradichaetes. c. ornamentation of sternal shield. d. ventral view of Parholaspulus excentricus. e. ventral view of Neparholaspis arcuatus. f. ventral view of Neparholaspus simplex. g. ventral view of Gamasholapis asiaticus).

sclerotized line and some oval pits and reticulate sculptural pattern, genital and ventrianal shields with reticulate sculptural pattern, genital shield with some shallow pits. Peritrematal shield fused to ventrianal shield. Previous record from Korean Peninsula. Distribution. Malaysia and Korean peninsula. Remarks. This is the first record in Korean Peninsula.

\section{Holaspina alstoni (Evans, 1956)}

New localities. As662 Republic of Korea, Prov. Jeju, Halla-san National Park, same site moss and soil samples (four different items) were taken from mosses, detri- tus, litter and upper layers of soil, 30.X.1993, leg. Peregovits, L. and Ronkay, L. As665 Democratic People's Republic of Korea, Prov. Jeju, Halla-san National Park, sandy soil with small rocks, 30.X.1993, leg. Peregovits, L. and Ronkay, L.

Previous record from Korean Peninsula. This species was described from Korean Peninsula by Lee \& Lee (2000). Distribution. Palearctis.

Gamasholaspis browingi (Bregetova \& Koroleva, 1960) New localities. As583 Democratic People's Republic of Korea, Kumquarg-san, forest leaf litter, 07.IX.1989, leg. 
Szollát, Gy.

Previous record from Korean Peninsula. This species are recorded from the Korean Peninsula by Lee \& Lee (2000).

Distribution. Russia and Korean Peninsula.

\section{Gamasholapis asiaticus Petrova, 1967 (Fig. 2g)}

New localities. As964 Republic of Korea, Gangwon province, Inje-gun, Seorak Mts, Misi-ryeong pass, beneath the rest area, forest brook, deciduous rocky forest, open grassland and rocks, $745 \mathrm{~m}, \mathrm{~N} 38^{\circ} 12.963^{\prime} \mathrm{E} 128^{\circ} 26.189^{\prime}$, 10.IX.2010, leg. Murányi, D.

Short description. Sternal shield, genital and ventrianal shields with reticulate sculptural pattern and some shallow pits. Peritrematal shield not fused to ventrianal shield, ventrianal shield longer than wide.

Previous record from Korean Peninsula. -

Distribution. Russia and Korean Peninsula.

Family Podocinidae Berlese, 1916

\section{Neoparasitus scleoides Ishikawa, 1969}

New localities. Korea2: Republic of Korea, Seoul, Korea University, outside Dukso farm, 11/08/2013., wet leaf litter under an unknown tree, 11.VIII.2013, leg. J. Kontschán.

Previous record from Korean Peninsula. Democratic People's Republic of Korea, Pyongyang City (Kontschán et al., 2014).

Distribution. Japan and Korean Peninsula.

Family Veigaiidae Oudemans, 1939

\section{Veigaia carpillaris Tseng, 1994 (Fig. 3g-h)}

New localities. As662 Republic of Korea, Prov. Jeju, Halla-san National Park, same site moss and soil samples (four different items) were taken from mosses, detritus, litter and upper layers of soil, 30.X.1993, leg. Peregovits, L. and Ronkay, L.

Short description. Podonotal and opisthonotal shields fused on central area, only two lateral incisions can be seen. These two shield covered by reticulate sculptural pattern and bearing smooth and needle-like setae. Epistome with two lateral marginally serrate branches and a central branch which Y-shaped and apically bearing short hairs, near basis of central branch a M-shaped strongly sclerotized character situated.

Previous record from Korean Peninsula. -

Distribution. Taiwan and Korean Peninsula.

Remarks. This is the first record in Korean Peninsula.

\section{Veigaia anmashanensis Tseng, 1994 (Fig. 3e-f)}

New localities. As659 Republic of Korea, Prov. Jeju, Halla-san National Park, same site moss and soil sam- ples (four different items) were taken from mosses, detritus, litter and upper layers of soil, leg 30.X.1993, leg. Peregovits, L. and Ronkay, L.

Short description. Podonotal and opisthonotal shields fused on central area, only two lateral incisions can be seen. These two shield covered by reticulate sculptural pattern and bearing smooth and needle-like setae. Epistome with two lateral marginally serrate branches and a central branch which Y-shaped and apically bearing short hairs.

Previous record from Korean Peninsula. -

Distribution. Taiwan and Korean Peninsula.

Remarks. This is the first record in Korean Peninsula.

Family Parasitidae Oudemns, 1901

Leptogamasus bicorniger Witalinski, 1977 (Fig. 3d) New localities. As664 Republic of Korea, Prov. Jeju, Halla-san National Park, leaf litter and soil, 30.X.1993, leg. Peregovits, L. and Ronkay, L.

Short description. Holodorsal shield present, peritrematal shields fused to ventrianal shield. Genital shield apically peaked, endogyneum with teeth.

Previous record from Korean Peninsula. -

Distribution. East Europe and Asia.

Remarks. This is the first record in Korean Peninsula.

\section{Neogamasus insignis (Holzman, 1969) (Fig. 3c)}

New localities. As235 Democratic People's Republic of Korea, Prov. South Pyongan: Pyongyan, Pyongyan Hotel garden, soli sample of Acari, 21.VIII.1971, leg. Papp, J. and Horvatovich, $\mathrm{S}$.

Short description. Holodorsal shield divided into podonothal and opisthonotal shields. Setae on palp genu marginally serrate. Endogyneum with big teeth. Tectum with 3 apical process which similar in shape and length to each other.

Previous record from Korean Peninsula. -

Distribution. Europe and Asia.

Remarks. This is the first record in Korean Peninsula.

Family Trachytidae Trägårdh, 1938

\section{Iphidinychus kakumeiensis Hiramatsu \& Hirschmann, 1992 (Fig. 3b)}

New localities. As659 Republic of Korea, Prov. Jeju, Halla-san National Park, same site moss and soil samples (four different items) were taken from mosses, detritus, litter and upper layers of soil, leg 30.X.1993, leg. Peregovits, L. and Ronkay, L.

Short description. Dorsal body with dorsal and pygidial shields, marginal setae situated on small platelets. Sternal shield smooth, ventrianal shield covered by small oval pits and with needle-like setae. Genital shield trape- 

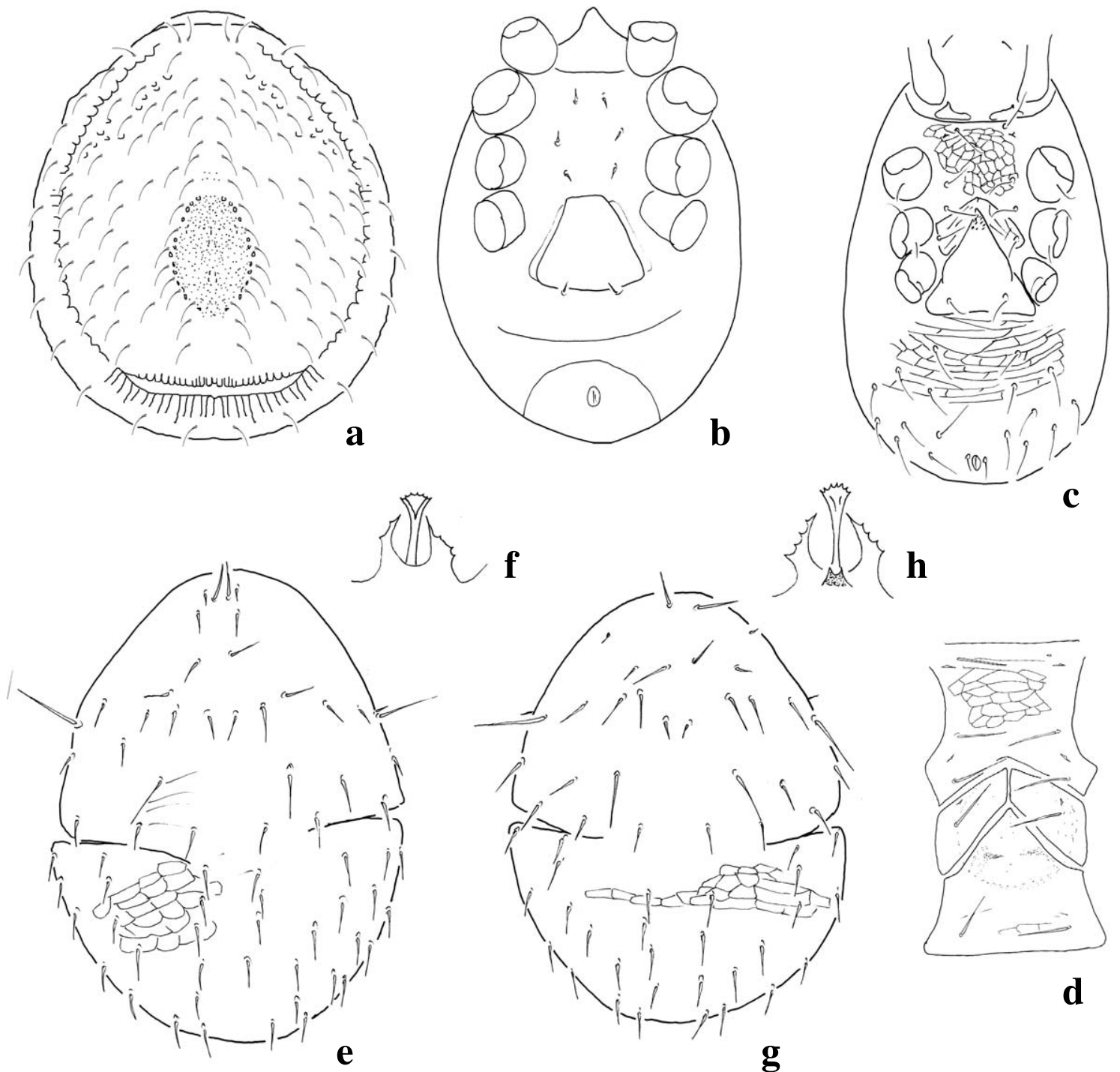

Fig. 3. Mesostigmatid mites from the Korean Peninsula III (a. dorsal view of Trigonuropoda sanguinea. b. ventral view of Iphidinychus kakumeiensis. c. ventral view of Neogamasus insignis. d. intercoxal area of Leptogamasus bicorniger. e. dorsal view of Veigaia anmashanensis. f. epistome. g. dorsal view of Veigaia carpillaris. h. epistome).

zoid with some oval pits on basal area, adgenital shield present.

Previous record from Korean Peninsula. -

Distribution. Japan and Korean Peninsula.

Remarks. This is the first record in Korean Peninsula.

Family Trigonuropodidae

\section{Trigonuropoda sanguinea Hirschmann \& Hiramatsu,} 1977 (Fig. 3a)

New localities. As664 Democratic People's Republic of Korea, Prov. Jeju, Halla-san National Park, leaf litter and soil, 30.X.1993, leg. Peregovits, L. and Ronkay, L. Short description. Dorsal shield covered by oval pits, central area with smooth surface. Genital shield of male rounded and situated between coxae III. Gnathosomal setae h1 wide and a little phylliform.

Previous record from Korean Peninsula. -

Distribution. Japan, Taiwan and Korean peninsula.

Remarks. This is the first record in Korean Peninsula.

Family Uropodidae Kramer, 1882

\section{Uropoda spiculata Hirschmann, 1972}

New localities. As664 Democratic People's Republic of Korea, Prov. Jeju, Halla-san National Park, leaf litter and soil, 30.X.1993, leg. Peregovits, L. and Ronkay, L. Previous record from Korean Peninsula. Republic of 

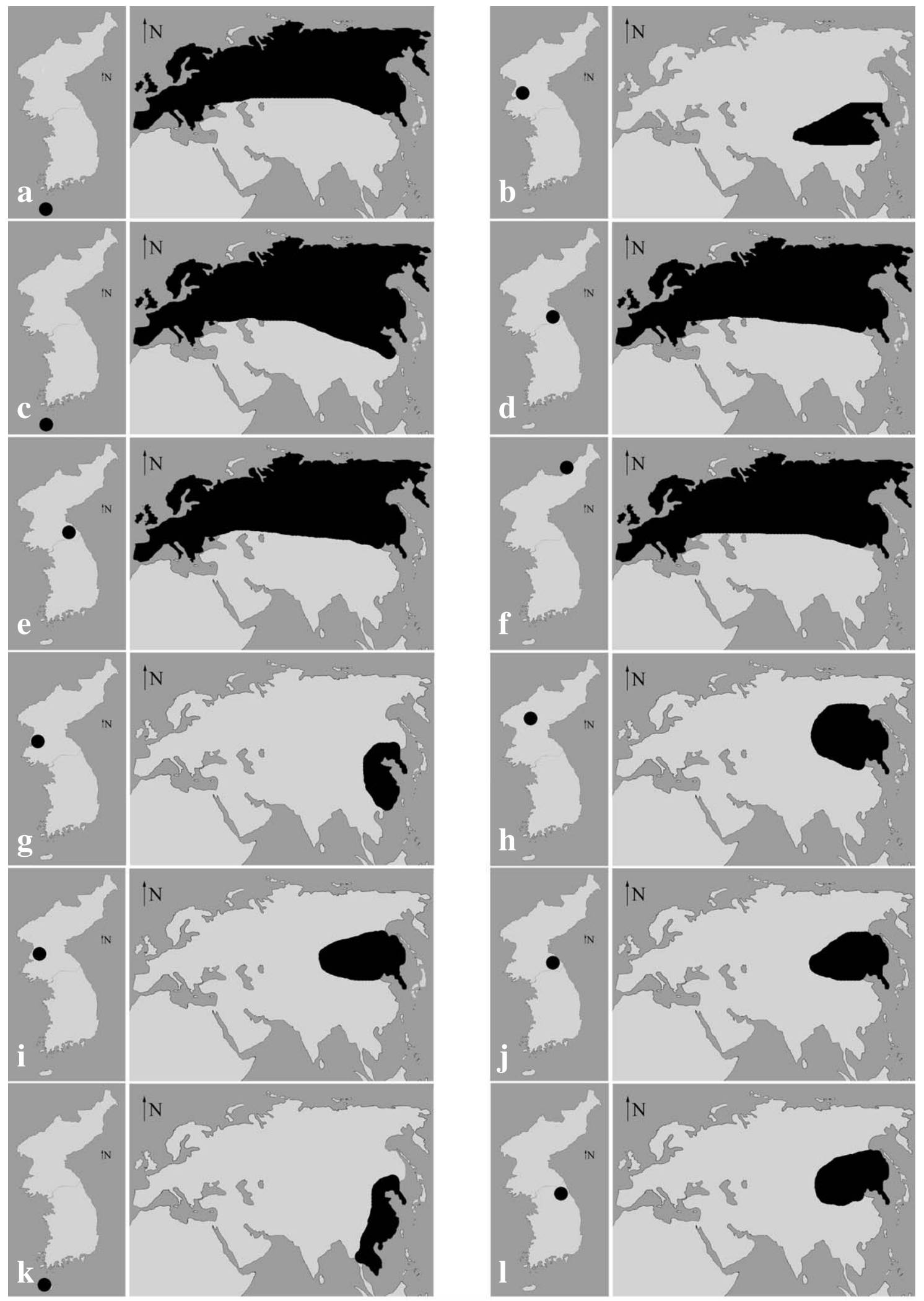

Fig. 4. Occurrence of Mesostigmatid mites in the Korean Peninsula and in the Palearctic I (a. Lasioseius furcisetus. b. Cheiroseius nepalensis. c. Cheiroseius curtipes. d. Hypoaspis imitates. e. Hypoaspis presternalis. f. Pseudoparasitus placentulus. g. Gamasiphis novipulchellus. h. Parholaspulus bregetovaae. i. Parholaspulus paradichaetes. j. Neparholaspis arcuatus. k. Neparholaspus simplex. 1. Gamasholapis asiaticus). 

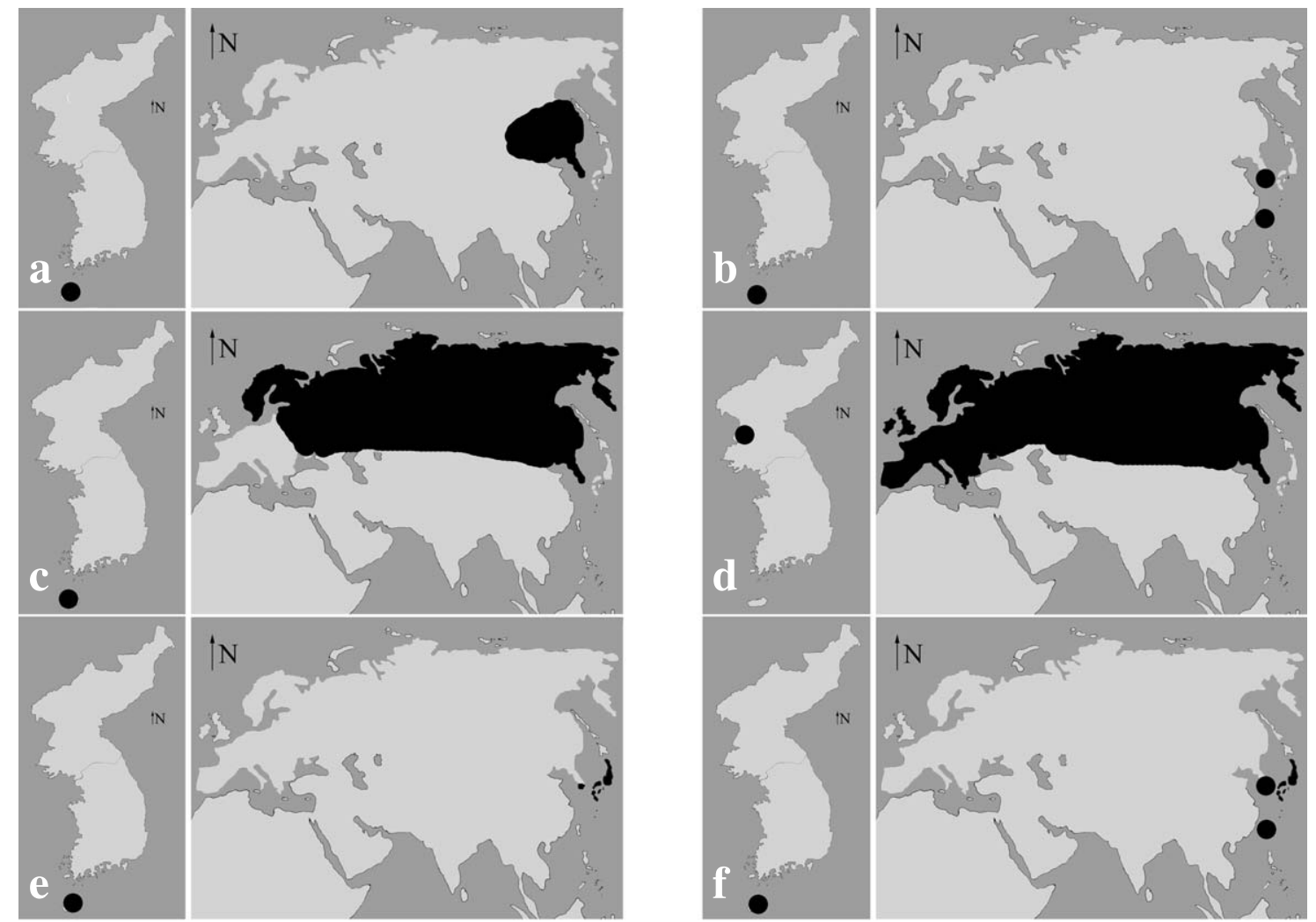

Fig. 5. Occurrence of Mesostigmatid mites in the Korean Peninsula and in the Palearctic II (a. Parholaspulus excentricus. b. Veigaia carpillaris and Veigaia anmashanensis. c. Leptogamasus bicorniger. d. Neogamasus insignis. e. Iphidinychus kakumeiensis. f. Trigonuropoda sanguinea).

Korea, Jeju-do (Kontschán et al., 2012).

Distribution. Japan, Vietnam and South-Korea.

Discourellidae Baker \& Wharton, 1952

\section{Discourella modesta (Leonardi, 1899)}

New localities. As583 Democratic People's Republic of Korea, Kumquarg-san, forest leaf litter, 07.IX.1989, leg. Szollát, Gy.

Previous record from Korean Peninsula. Republic of Korea, Gyeonggi-do (Kontschán et al., 2012).

Distribution. Europe and Korean Peninsula.

\section{Discourella koreae Hirschmann, 1971}

New localities. As583 Democratic People's Republic of Korea, Kumquarg-san, forest leaf litter, 07.IX.1989, leg. Szollát, Gy.

Previous record from Korean Peninsula. Republic of Korea, Gyeonggi-do, Democratic People's Republic of Korea, Gangwon-do, Democratic People's Republic of Korea, Pyeonganbuk-do (Kontschán et al., 2012).

Distribution. Korean Peninsula.

Remarks. Endemic Korean species.

\section{Zoogeographical notes}

Of the 34 newly reported species reported from the DPRK and the ROK, 18 species were reported from soil samples from the DPRK, 13 were reported from the ROK, and two species were reported from both the DPRK and the ROK. Additionally, eight species were reported from Japan and 19 species from Russia and the other parts of Palearctic region (like China). Two species were only reported from the Korean Peninsula while four species were reported from the Oriental region (Taiwan (2), Vietnam (1), and Malaysia (1). A total of 13 species reported from the DPRK were also reported from the Palearctic, including Russia, while four species were only reported from the Oriental, including Japan, regions, according to these results maybe the Palearctic impact is higher here then the Oriental and Japanese. Republic of Korea differs from the Democratic People's Republic of Korea on the basis of the newly reported species, most species (9) were found here with Japanese or Oriental connection (mostly in Jeju Island). The species number is six in this case of these species which have Russian or Palearctic relatives, therefore on the basis of the newly presented species the fauna of Republic of Korea are 
closer to the Japanese or Oriental faunas.

\section{ACKnowledgements}

This work was supported by a grant from the National Institute of Biological Resources (NIBR), funded by the Ministry of Environment (MOE) of the Republic of Korea(NIBR No. 2014-01-213).

\section{REFERENCES}

Błaszak, C. 1976a. Xenozercon glaber gen. nov., sp. nov. (Acari, Zerconidae) from Democratic People's Republic of Korea. Bulletin of Academy of Polish Sciences 24(1): 33-36.

Błaszak, C. 1976b. Systematic studies on family Zerconidae II. Democratic People's Republic of Korea $\mathrm{n}$ Zerconidae (Acari, Mesostigmata). Acta Zoologica Cracoviensia 21(16):527-552.

Kontschán J., S.J. Park, T.J. Yoon and W.Y. Choi. 2012. New Uropodina records and species from the Korean Peninsula (Acari: Mesostigmata). Opuscula zoologica Budapest 43:169-177.

Kontschán, J., S.J. Park, T.J. Yoon and W.Y. Choi. 2013. Uropodina mites from Korean Peninsula (Acari: Mesostigmata). AdLibrum Kiadó, Budapest, 80 p.

Kontschán, J., S.J. Park, J.W. Lim, J.M. Hwang and H.J. Seo. 2014. New Mesostigmata records and species from the Korean Peninsula. Opuscula Zoologica Budapest 45 (1): 17-23.

Kontschán, J., S.J. Park, J.W. Lim, J.M. Hwang and H.Y. Seo. 2014. Contribution to the mite (Acari) fauna of the Korean Peninsula. Journal of Species Research 3(1):6378.

Krantz, G.W. and D.E. Walter. 2009. A manual of acarology. Third Edition. Texas Tech University Press, Lubbock, Texas, $807 \mathrm{pp}$.

Lee, S.-Y. 1994. A taxonomic studies on genus Asca (Ascidae: Mesostigmata) in Korea. Master Thesis, $71 \mathrm{p}$.

Lee, S.-Y. and W.-K. Lee. 1996. Three soil mites of the family Parholaspidae and Podocinidae (Mesostigmata, Acari) from Korea. Korean Arachnology 12(2):131-137.

Lee, S.-Y. and W.-K. Lee. 1998. Four mites of the genus Lasioseius (Acari: Meostigmata: Ascidae) from Korea. The Korean Journal of Systematic Zoology 14(1):13-19.

Lee, W.-K. and S.Y. Lee. 2000. Taxonomic Study of Parholaspid Mites (Acari: Mesostigmata) in Korea. The Korean Journal of Systematic Zoology 16(1):105-112.

Lee, W.-K., S.-Y. Lee and M.-O. Ryu. 1997. Taxonomic Studies on the genus Asca (Ascidae: Mesostigmata) in Korea II.-Description of two new species. The Korean Journal of Systematic Zoology 13(1):33-44.

Lim, J.-W. 2001. A taxonomic study on the family Zerconidae (acari: Mesostigmata) in the Korean Peninsula. $\mathrm{PhD}$ Thesis, $130 \mathrm{p}$.

Submitted: October 27, 2014

Revised: February 23, 2015

Accepted: February 25, 2015 
Appendix 1. List of the soil samples surveyed.

As199 Democratic People's Republic of Korea, Prov. South Phenan: De-sang san, 12 km NE from Pyongyang, dry SW slopes of the mountain, Thick coniferous litter under a pine tree, 27.V.1970, leg. Mahunka, S. and Steinmann, H.

As215 Democratic People's Republic of Korea, Prov. Kanwon: Kum-gang san, Guriong chon riverside northern slope, mosses from soil surface and cliff-side, 01.VI.1970, leg. Mahunka, S. and Steinmann, H.

As216 Democratic People's Republic of Korea, Prov. Kanwon: Kum-gang sen, Guriong chon, riverside northern slope, litter and underlying ground from below coniferous trees, 01.VI.1970, leg. Mahunka, S. and Steinmann, H.

As230 Democratic People's Republic of Korea, Prov. Ryang-gang: Mt. Pektusan soil sample of Acari ectracted, 26.VIII.1971, leg. Papp, J. and Horvatovich, S.

As235 Democratic People's Republic of Korea, Prov. South Pyongan: Pyongyan, Pyongyan Hotel garden, soli sample of Acari, 21.VIII.1971, leg. Papp, J. and Horvatovich, S.

As273, Democratic People's Republic of Korea, Prov. South Pyongan: Pyongyan, De-sang san, 12 km NE from Pyongyan, moss sample from a coniferous wood, 18.VII.1975, leg. Papp, J. and Vojnits, A.

As279 Democratic People's Republic of Korea, Prov. South Pyongan: Pyongyan, De-sang san, 12 km NE from Pyongyan, litter sample from a coniferous wood, 18.VII.1975, leg. Papp, J. and Vojnits, A.

As282 Democratic People's Republic of Korea, Prov. Ryang-gang: Chann-Pay plateau, Mt. Pektusan, Mu-do-bong, moss and lichen samples from the upper level of Larix-Betula forest, 25.VI.1975, leg. Papp, J. and Vojnits, A.

As541 Democratic People's Republic of Korea, South Hwanghae Province, Haeju, Mt. Suyong-san, moss, 30.XI.1986, leg. Demeter, A.

As557 Democratic People's Republic of Korea, North Pyongan Prov., Mt. Myohyang-san, material extracted of the litter of a mixed forest on the bank of thes stream Hyangsam by Moczarsky-Winkler-funnel, 08.X.1987, leg. Korsós, Z. and Ronkay, L.

As572 Democratic People's Republic of Korea, Kangwon Province: Kumang-san, Onjong-ri, sample taken from pitfall traps baited with beer in Pinus densiflora-forest, 21-17.VI.1988, leg. Merkl, O. and Szél, Gy.

As573 Democratic People's Republic of Korea, Kangwon Province: Kumang-san, Onjong-ri, sifting forest litter and rotten trunks of Pinus densiflora, 19.06.1988, leg. Merkl, O. and Szél, Gy.

As583 Democratic People's Republic of Korea, Kumquarg-san, forest leaf litter,07.IX.1989, leg. Szollát, Gy.

As659 Republic of Korea, Prov. Jeju, Halla-san National Park, same site moss and soil samples (four different items) were taken from mosses, detritus, litter and upper layers of soil, leg 30.X.1993.10, leg. Peregovits, L. and Ronkay, L.

As660 Republic of Korea, Prov. Jeju, Halla-san National Park, same site moss and soil samples (four different items) were taken from mosses, detritus, litter and upper layers of soil, 30.X.1993, leg. Peregovits, L. and Ronkay, L.

As661 Republic of Korea, Prov. Jeju, Halla-san National Park, same site moss and soil samples (four different items) were taken from mosses, detritus, litter and upper layers of soil, 30.X.1993, leg. Peregovits, L. and Ronkay, L.

As 662 Republic of Korea, Prov. Jeju, Halla-san National Park, same site moss and soil samples (four different items) were taken from mosses, detritus, litter and upper layers of soil, 30.X.1993, leg. Peregovits, L. and Ronkay, L.

As664 Democratic People's Republic of Korea, Prov. Jeju, Halla-san National Park, leaf litter and soil, 30.X,1993, leg. Peregovits, L. and Ronkay, L.

As665 Democratic People's Republic of Korea, Prov. Jeju, Halla-san National Park, sandy soil with small rocks, 30.X.1993, leg. Peregovits, L. and Ronkay, L.

As964 Republic of Korea, Gangwon province, Inje-gun, Seorak Mts, Misi-ryeong pass, beneath the rest area, forest brook, deciduous rocky forest, open grassland and rocks, $745 \mathrm{~m}, \mathrm{~N} 38^{\circ} 12.963^{\prime}$ E128 $26.189^{\prime}$, 10.IX.2010, leg. Murányi, D.

Korea1: Republic of Korea, Seoul, Korea University, Dukso farm, wet leaf litter under an unknown tree and under Gingko biloba, 11.VIII.2013, leg. Kontschán, J.

Korea2: Republic of Korea, Seoul, Korea University, outside Dukso farm, 11/08/2013., wet leaf litter under an unknown tree, 11.VIII.2013, leg. Kontschán, J. 